\title{
Shared Emotions and a Forum for Gossiping
}

\author{
Nuances in Danish Celebrity Journalism
}

\author{
Kirsten SPARRE
}

Journalism about celebrities and royals is extremely popular in Denmark. Between them, the four weekly celebrity magazines in Denmark had 2.4 million readers each week in the first half of $2001 .^{1}$

Stories about royals in particular also take up considerable space and time in other printed media and on public service television. When the Norwegian Crown Prince Haakon married commoner Mette-Marit in August 2001, two Danish public service stations transmitted the wedding ceremony and the party afterwards, and 2.6 million Danes followed events in Oslo as compared to only 1.8 million Norwegians. ${ }^{2}$ Interest in those who have become public figures by participation in reality shows like the Robinson Expedition and Big Brother is also high. In the spring of 2001, Danish newspapers and celebrity magazines printed a total of 969 articles about the Big Brother series alone. ${ }^{3}$

Recent international research also suggests that celebrity has become increasingly popular. Reassessing Galtung and Ruge's classic article on news values (Galtung and Ruge 1965), Harcup and O'Neill arrived at a more contemporary set of news values that put celebrity almost at the top. The authors analysed 1276 news articles that had been published as page leads on all news pages in the month of March 1999 in three British national newspapers, the tabloid Sun, the broadsheet Daily Telegraph, and the Daily Mail. Harcup and O'Neill concluded that celebrity has become a major factor in determining whether a news story is selected for inclusion in a newspaper. "The UK press seems obsessed with celebrities such as TV soap stars, sports stars, film stars, and, of course, royalty", the

Centre for Journalism and Further Education, Olof Palmes Allé 11,DK-8200 Arhus N, sparre@ tdcspace.dk authors remarked (Harcup and O'Neill 2001). An American study from the Committee of Concerned Journalists compared changes in news values across television newscasts, national newspapers and print news magazines for the years 1977, 1987 and 1997. This study showed that the number of stories about celebrity, entertainment or celebrity crime tripled during the period, from one in every 50 stories in 1977 to one in every 14 stories in 1997 (Committee of Concerned Journalists 1998).

The high number of stories about celebrities has led to worry and unease amongst journalists and academics concerning the quality of media content and falling journalistic standards. But do more stories about celebrities necessarily reflect falling standards, or are they merely a sign that a journalistic paradigm different from the prevailing political one is coming more to the fore? Any discussion of such questions is inhibited by the fact that, in spite of its popular appeal and the anxiety from professional elites, there has been very little research on the working methods, underlying dynamics, and patterns of development in celebrity journalism. There is quite simply a lack of nuance in this area.

Over the past two years, a long-term research project from the Danish Centre for Journalism and Further Education has tried to fill some of that gap. The project discusses how different types of media value stories about celebrities, and how such stories contribute to processes of tabloidization. The project has looked at how journalists in Denmark gather information about celebrities and the royals, which turned out to be a far more nuanced process than conventional wisdom would suggest. Finally, the project has described some of the methods and dynamics that govern the relationship between celebrity media and their viewers/readers. What do people gain from celebrity journalism, and to what extent do stories have to be factual and accurate in 
order to be good? Do such stories live up to ideals of good journalism?

\section{Approach and Methodology}

It is a central starting point for the project to view celebrity journalism as exactly that: Journalism. The celebrity news in our study qualified as journalism because it fulfilled a number of professional criteria such as

- having a high degree of topicality

- being events-based

- relying on journalistic genres such as news, interviews, features and voxpops

- being based on identified sources and observations of actual events

- exercising a certain degree of criticism of sources

Based on this premise, CFJE's project has looked at celebrity journalism through three case studies of the output of the four Danish weekly celebrity magazines Billed-Bladet, Se og $\mathrm{H} \phi r$, Her og $\mathrm{Nu}$, and Kig Ind; the two popular newspapers Ekstra Bladet and B.T.; the three broadsheet papers Berlingske Tidende, Morgenavisen Jyllands-Posten, and Politiken; the main news casts of the two public service television stations DR 1 and TV 2; and in two case studies also the output from the main Danish news agency Ritzau's Bureau. ${ }^{4}$ A total of 1,743 articles and tv items together with 340 pictures formed the empirical basis for the case studies, which were later supplemented with observations and qualitative interviews with a number of journalists, photographers and editors.

One case covered the period from the birth of the first child to the Danish prince Joachim and princess Alexandra on 28 August 1999 to his christening on 6 November 1999. During that period, the magazines and news papers printed 648 articles about the new prince, while DR 1 showed a total of 5.3 hours and TV 27.4 hours of prince-related television including news, special news bulletins, and direct transmissions from his release from hospital and the christening ceremony. Another case followed the coverage of the second series of the reality-tv programme The Robinson Expedition from 6 September to 29 November 1999. In this series, 16 ordinary Danes spent 13 weeks on a deserted island surviving on little food and voting among themselves at regular intervals about who should be sent home. It was covered in 641 articles in magazines and newspapers, but did not attract attention from the television news broadcasts. A third case was a study of all celebrity news in all editions of the selected media during the week of 15 to 21 November 1999.

To be included in the latter case study, a celebrity news story should fulfil three main criteria: First, it should be a story about a person who is known by broad sections of society; second, the story should focus on personal aspects of that person's life; and third, the main aim of the story should be to satisfy the reader/viewer's curiosity about the person rather than giving them information they could use as citizens or consumers. These criteria made it possible to exclude stories in which celebrities act in a professional capacity, for instance as performers, tv hosts or as sources for a political story of the day. Stories that included evaluations of celebrities' professional conduct, such as reviews, or previews of upcoming events such as concerts were excluded.

\section{Celebrity - A News Value for Whom?}

It is obvious that celebrity is an important news value for weekly magazines that base their publications on tv listings and news about celebrities. But to what extent is celebrity an important news value for other types of media too?

Data from the general case study show that the frequency of celebrity stories is largely dependent on the underlying media ideology. The figure below is based on data derived by taking all celebrity news in the chosen media from one week's editions as a percentage of the total number of news stories in those media during that week.

The frequency of celebrity news differed widely depending on the value attached to celebrity by the different media types. The two newest celebrity magazines in Denmark, Her og $\mathrm{Nu}$ and Kig Ind, rely almost solely on celebrity stories, whereas the two older ones, Billed-Bladet and Se og Hor, also include stories that engage the curiosity of readers (a blue dog), involve them in the unusual fate of a noncelebrity (woman gave birth to siamese twins) or a round-up of dramatic world events. With 6-10 percent, celebrity is one of many important news values for popular newspapers. In the words of Kristian Lund, editor-in-chief of B.T., popular newspapers aim to bring people "the stories that everybody talks about"; one day that might be the birth of a son to supermodel Helena Christensen and the next day it might be a train crash. Celebrity is also a news value for broadsheet papers with a selfprofessed serious news agenda, but it is not a very 


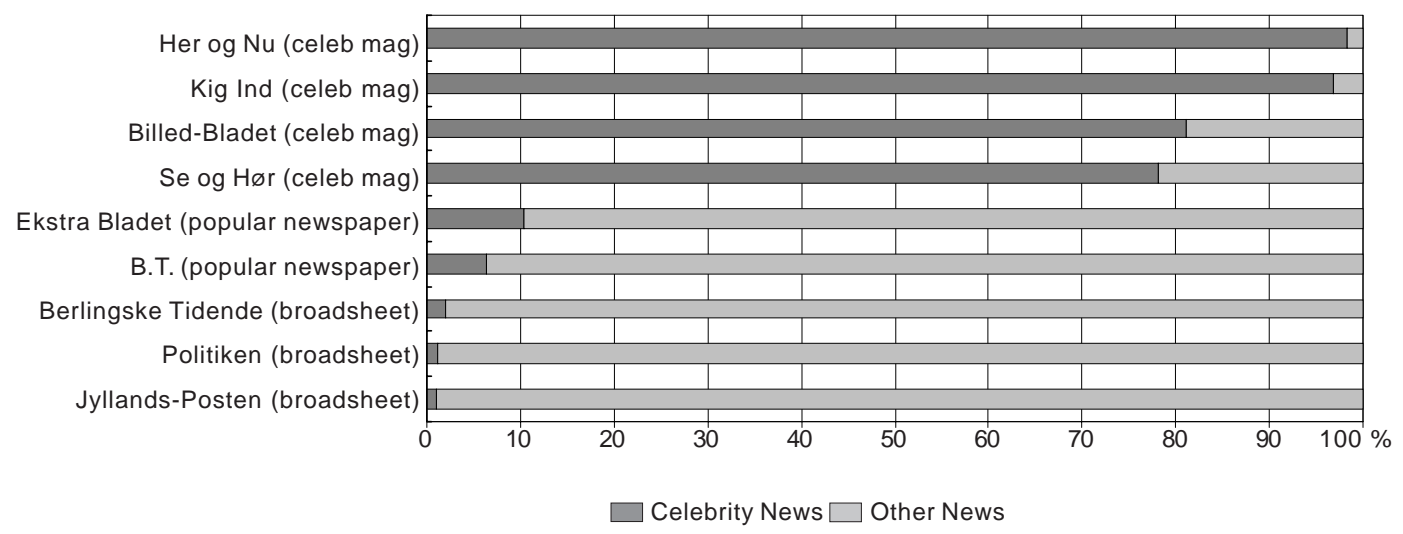

important one. Celebrity stories do appear, but are dwarfed by many other types of content. And finally, during the week of observation, there were only four very short celebrity news items on public service television newscasts.

\section{Celebrity and Tabloidization}

The figure above, however, does not tell the whole story about the importance of celebrity news to changes in the current practice of journalism in Denmark. Celebrity news belongs to a group of news stories that Stig Hjarvard has labelled tabloid news (Hjarvard 1999:182). Our case studies on the Robinson Expedition and the birth of a new Danish prince show how celebrity news coverage has contributed to a tabloidization process in popular newspapers as well as in broadsheet papers and public service news broadcasting.

Tabloidization has long been shorthand for a process of decline in the standards of news media. In the context of our study, however, tabloidization is discussed more neutrally as a tool to identify changes in journalistic work routines. Colin Sparks has defined tabloidization as a process whereby the share of stories about economic and political affairs is gradually reduced and whereby journalists come to rely more and more on the personal and individual experiences of interview persons as the main source for reporting and discussion (Sparks 1998:7). Our study adds a couple of further dimensions to the understanding of tabloidization.

\section{Parallel Realities}

Looking at the coverage of the reality tv series The Robinson Expedition, it became apparent that jour- nalists, particularly at celebrity magazines and popular newspapers, became engaged with the series as if it were reality rather than a construction. It is, of course, commonplace to cover constructed realities such as films and tv series, but this normally occurs at a certain distance from which journalists acknowledge the fictional element. But in this case, distinctions between the real reality and constructed reality became incredibly blurred in a number of ways: Descriptions of events and emotions on the island were presented side by side with stories about the lives participants were leading back in Denmark at the time of the broadcasting of the programmes. Participants became known by nicknames derived from their behaviour on the island. Stories about a participant's reaction to being sent away from the island, which took place during recording in early summer, could easily command a front page in November when the show was broadcast, and the next day the front page could be devoted to a minister resigning. Journalists and media were also more than happy to participate in the construction of a Robinson reality by, for instance, facilitating phone-in sessions where audiences could speak directly with participants in the series. Covering parallel types of realities is characteristic of what could be labelled reality journalism, and in the case of the Robinson Expedition, it contributed to a sense that what happened on the island was real and not an interesting social experiment conducted at the request of television producers.

The "real" reality to which journalists responded was, of course, that massive numbers of viewers experienced real emotions through their involvement with the series. But from a journalistic point of view, it must be considered part of a tabloidization process when journalists, in follow-up coverage to a 
tv series, do not distinguish between real events and tv-constructed reality - when a tear shed in Robinson is just as authentic, and often more intensely reported, than a tear shed by a mother who has lost her son in a real-life earthquake.

\section{Tabloidization in Spots}

The Robinson Expedition was never reported in a tabloid fashion in Danish broadsheets and public service television newscasts. This is not because these media never do tabloid style reporting, but it appears that certain conditions have to be met before such reporting occurs. The Robinson Expedition did not fulfil these criteria, but another event in the late summer and fall of 1999 did: The birth of a son to prince Joachim and princess Alexandra.

This was an important event on any media scale, and all media surveyed covered it intensively. For broadsheet newspapers and public service television, the tabloid elements were most evident in the style of presentation, the choice of topics from the private sphere, and the reliance on interviews that emphasized the personal experience of the event, ranging from the royal parents themselves to people in the street. Emotions - national as well as personal - were at the core of the coverage and journalists on tv and broadsheet newspapers dispensed with their usual critical approach to coverage and presented the news in positive and emotional language.

The style and amount of prince-related coverage in broadsheet papers and tv newscasts contrast sharply with the data about celebrity news coverage from an ordinary week. And this points to a key issue in understanding tabloidization processes in such media. Here tabloidization can happen occasionally in the context of particularly important issues with an emotional bearing on the nation state, such as events in the royal family or Danes winning international sports championships. National importance serves as an underlying frame and news value that seems to legitimise tabloid style reporting in media that would normally frown upon such practices.

\section{Three Types of Celebrity Journalism}

The relationship between journalists and celebrities is shrouded in mystique on a continuum of opposite extremes. At one end of the continuum, popular myth holds that celebrities are systematically victimized, as stories are obtained against their will and journalists employ very intrusive methods. At the other end, however, is the equally persistent assumption that the majority of celebrities are more than happy to promote themselves to the media to gain financial and other advantages.

But our findings indicate a much more complex picture. In Danish celebrity journalism, it is possible to distinguish between three different groups of celebrities for which journalists have different ways of obtaining stories.

In general, journalists do their outmost to meet Danish celebrities face-to-face and to obtain direct quotes. This is done either through specially arranged interviews or by turning up at celebrity events such as release parties and film premiers, which are based on the premise of providing a platform for interaction between celebrities and the media. Journalists working at weekly celebrity magazines in particular invest considerable time in building trust with Danish celebrities and, for instance, allow them to read texts of longer interviews before they are printed. In terms of content, the articles mainly discuss issues that the interviewee feels comfortable talking about.

The relationship between journalists and Danish celebrities is governed by a complex set of legal rules, professional ethics and personal morals of editors and journalists. Within this framework, journalists and celebrities constantly negotiate the terms for particular stories: Will the celebrity meet with the journalist and photographer at home or at a cafe? To what extent is the celebrity prepared to go into details about his or her love life? This is a give and take relationship that is ultimately governed by the need on the part of journalists to obtain a story with the consent of the celebrity, as consent frees the journalists from charges under the Danish Media Liability Act that they have infringed upon the celebrity's right to privacy.

Celebrity journalists behave quite differently towards Danish royals, who are mostly covered from a distance. This is not a preferred option, but is the result of several factors. First, while the royal family does cooperate with the media about coverage of certain events from the private sphere, such as weddings, christenings, and funerals, such events are easily superseded by the almost insatiable demand for royal news. Many journalists fill this vacuum by obtaining their day-to-day stories about members of the Danish royal families simply by being in attendance whenever they turn up for official or semi-official engagements. On certain occasions, journalists may also keep particular members of the royal family under constant observation. Neither of these methods is likely to put journalists in a posi- 
tion to speak directly with the royals. Second, by virtue of their position in society, Danish royals are not immediately accessible in the same way as other celebrities. Generally, they cannot be reached directly on the phone and the Danish royal family does not employ a specific press secretary, so Danish journalists do not enjoy the same kind of access to the royals as to ordinary celebrities.

Consequently, celebrity journalism about the Danish royal family is a mixture of stories obtained partly through cooperation, partly through observation, and partly through speculation and interpretation of royal behaviour. The latter method has been used extensively in coverage of the love life of crown prince Frederik, where for instance his repeated trips to Australia during the past year have led some celebrity magazines to conclude that he must have a girlfriend there even if more solid evidence of that hypothesis only started to emerge in November 2001.

The final group of celebrities consists of foreign royals and celebrities. Here most Danish journalists obtain their stories second or third hand from sources such as foreign newspapers and websites, and by trading with international freelancers and picture agencies. Rarely do Danish journalists interview foreign celebrities personally. Consequently, many of the stories about foreign celebrities in Danish media are far spicier than stories about their Danish counterparts and these stories often show foreigners half-naked and expose less-than-flattering behaviour. As Bo Andersen, editor-in-chief of weekly celebrity magazine $\mathrm{Her}$ og $\mathrm{Nu}$, said: "The distance means that people from Hollywood easily become cartoon figures whom we are prepared to hear more sleazy stories about."

\section{Factuality and Celebrity Journalism}

One of the most contentious professional issues with regard to celebrity journalism is its attitude towards factuality. Can stories about celebrities be believed or not? However, after looking at celebrity journalism for more than two years, we find that a much better question is whether audiences are actually looking for absolute factuality in celebrity news?

It should be noted that stories about Danish celebrities often appear very factual as they - unlike the royal family - can sanction media publishing as inaccurate information by withdrawing their cooperation or lodging a complaint with the Danish Press Council. But particularly with respect to the Danish royal family, celebrity journalists quite often employ a version of factuality different from that of traditional fact-based journalism.

In traditional fact-based journalism, facts are used to create as complete a picture of a story as possible. A story about the crown prince's frequent trips to Australia would be deemed irrelevant unless some competent person would comment and explain what he was doing there. Celebrity journalism, however, may take its starting point in the factual observation that the crown prince has been going to Australia quite often recently and use that as a frame for the picture of the story. The area in the middle of the picture would then be opened for discussion with the reader when the journalist offers an interpretation of why he goes there so often that is based on information other than direct and attributable quotes - for instance that he travels there because of a new love interest. This technique gives the reader an opportunity to engage in the story through active gossiping, which essentially involves evaluating and interpreting the behaviour of others. But it is important that the journalist present an interpretation that is believable and desirable - to suggest that the crown prince is undergoing treatment for alcohol problems out of the public eye in Denmark would probably not be accepted by the audience unless there was much firmer evidence for such a claim.

Does the gossiping technique threaten the credibility of individual stories as well as that of the journalistic profession in general? The answer depends, to a certain degree, on the sophistication of the audience. For the audience, the danger of the gossiping technique is obviously that, in order to make the story work, the journalist implicitly asks readers to question and disagree with certain story lines. Those who appreciate the technique may enjoy the individual story without losing faith in the general credibility of journalism. But for those who do not understand or accept the method, such a story may lead to doubts not only about a particular story itself, but about all other stories in the same media as well as the production process behind them. Unfortunately, there are differences in the skill and morality with which individual journalists and media apply the gossiping technique. Sometimes the gossip storylines go beyond journalism and lead the reader directly into the territory of fiction. However, that should not exclude the gossiping technique completely from the toolbox of good journalism - appropriately and ethically exercised, its main advantage is that it allows the reader to take part in the creation of the meaning of the text. This may, in fact, be the main explanation for the popularity of the method. 


\section{Engaging With the Audience}

The gossiping technique is part of the special dynamics that govern celebrity journalism and distinguish it from other types of journalism. Central to these dynamics is a very active relationship between journalism and consumers. Contrary to common wisdom, celebrity journalism, in order to succeed, demands a fair amount of activity on the part of its consumers.

First, consumers need to build up relationships with people in the public eye to such an extent that they are willing to invest in celebrity news products in order to learn more about them. Building relationships of that kind is a dynamic process that requires consumers to consume cultural products such as news, tv programmes, movies and music. That a personal relationship is necessary is amply illustrated by considering the lack of interest Danish consumers have in Swedish or Norwegian celebrity magazines, which are full of similar stories, but about people Danish consumers do not know.

Second, as John Langer (Langer 1998) pointed out in his study of tabloid news, celebrity journalism relies on the consumer being willing to use herself and her own life as a ruler against which to measure the lives of celebrities. Celebrity must be recognised as something extraordinary in order to create the tension necessary to consider the rather ordinary events in celebrity lives (shopping, falling in love, having a baby) interesting and perhaps more interesting than the same event in the consumer's own life. And third, some of the presentation techniques, such as the gossiping technique and the sharply angled front-page headlines, also require active participation and acceptance from consumers if they are to work. Editors of weekly celebrity magazines in Denmark say that gaining acceptance from consumers is an ongoing process, where the main negotiation takes place at newspaper stands as consumers decide whether to reward good headlines by buying the publication or to punish it for last week's edition by leaving it on the shelf.

\section{Changes Ahead?}

With few and notable exceptions, Danish celebrity journalism is nice and cosy and inoffensive. And editors of weekly celebrity magazines in Denmark believe that this state of affairs is unlikely to change in the foreseeable future, because the Danish audience will not accept scandal mongering or sensation- alism in their magazines. But is this correct? During our research the perception of the reader and his and her wishes emerged as a major factor in explaining editorial decision making concerning the ways in which celebrity news is covered and what journalistic standards should apply to newsgathering efforts. The huge demand for any story about the Danish royal family has, for instance, led the celebrity magazine Billed-Bladet to abandon a long-held policy allowing members of the royal family to personally decide whether they accept being photographed when they appear in public places on personal business. Now photographs are taken before consent is asked for another picture. If the answer is no, the magazine reserves the right to publish the first picture, which was taken before personal interaction. Billed-Bladet not only markets itself as the Danish royal magazine, but also prides itself on particularly high ethical standards compared to the other celebrity magazines. Still, perceptions of market demands have changed principles for newsgathering at the magazine, and the question is how far audiences can push journalistic principles before they are met with resistance from the newsroom?

Pressures against the independence of celebrity journalism also come from the process of constructing celebrity. So far, Danish celebrity journalism has been based on a fairly free exchange between celebrities and journalists of information that will receive attention. But exchange rates are rising. There are examples of payment to Danish celebrities for exclusive pictures from weddings, although the scope is nowhere near the situation in Britain, where some celebrities generate major incomes for themselves by selling life events to celebrity magazines (Bundgaard 2001). Editors complain that celebrities make demands on how they want to appear in the news, although the situation is nowhere near that in Hollywood, where journalists must negotiate with PR agents for access to interviews with film stars. But Danish celebrity journalism is heavily involved in the construction of celebrity, and with the appearance of reality tv, the process has become intensified to the point where journalistic independence could be in jeopardy. In 2001, the Danish popular newspaper Ekstra Bladet made an arrangement with a Danish television station whereby, regardless of events in the surrounding world, they would publish news from the first Danish series of the reality-tv programme, Big Brother, every day in exchange for exclusive access to good stories and the showing of the newspaper's logo in connection with the broadcasts. ${ }^{5}$ 


\section{Potential for Growth with no Buyers?}

As a whole, the CFJE project has described a lively and economically sustainable journalistic paradigm that gives its readers and viewers room and tools for engaging in the world from an emotional viewpoint. It is a paradigm with huge potential for growth in the near future. For instance, future researchers believe that the products of the future will be based on giving consumers emotional experiences through storytelling (Jensen 1999). And the Danish professor of media studies Ib Bondebjerg believes that the focus on the nation state as the main frame of reference for understanding events in the world is being replaced by public figures. These public figures will serve as concrete symbols that will help us understand life in the globalised world by giving us access to their private lives so that we can see and recognise patterns, thoughts and feelings from their lives in our own (Niels Bjørn 2000).

But are Danish media ready for this challenge? Generally the answer is no. Asked directly, none of the editors of Danish celebrity magazines had visions of journalistic missions that extend beyond serving the market. It is a form of naivety that can be damaging if the same editors wish to be able to stay within the parameters of a journalistic paradigm, rather than becoming dependent cogwheels in the larger production of celebrity through the constructed authenticity of reality television.

The problem at broadsheet papers and public service television stations is slightly different. Here celebrity is becoming news - often to a much larger degree than journalists and editors are prepared to admit - and when this happens, the coverage imitates that of more established celebrity media both in terms of contents and form. With its strong traditions of in-depth portraits and interviews, it would be relatively easy for $t v$ and broadsheet papers to expand on celebrity stories and make them more interesting without necessarily losing the interesting and emotional elements. This has not happen thus far, which is probably largely due to a fear of engaging seriously with the topic in the editorial offices at these media. The consequence seems to be a rather unconscious copying of methods from celebrity magazines and popular newspapers in their own celebrity stories, instead of taking up the challenge of renewing and improving on a type of journalism that will probably continue to rise in popularity.

\section{Notes}

1. Based on information from www.aller.dk and www.dmu-mags.dk

2. Information from TV 2's homepage www.tv2.dk on 28 August 2001

3. Information based on research compiled by Observer Danmark and printed in Michael Grønnegaard and Kaj Høivang: "Tv scorer millioner på presseomtale", Børsen, 16 May 2001

4. The media chosen for study included all weekly celebrity magazines, both the popular newspaper and the three main broadsheet papers based on circulation. There are other daily newspapers in Denmark with a national circulation, but none of these has numbers of staff that would allow them to devote significant resources to covering the royal family on special occasions - and as that was one of the aspects we were interested in studying, they were excluded from the study.

5. The arrangement was described in two articles in the Danish trade journal for journalists, JOURNALISTEN, no. 3, 2001

\section{References}

Bjørn, Niels: "Globalt privatliv" at URL: www. kommunikationsforum.dk/ugensprofil/interview _ib_bondebjerg.htm

Bundgaard, Bente (2001) "Kendthedens pris" in Kirsten Sparre \& Lars Kabel: Den glade journalistik, Aarhus: Ajour.

Committee of Concerned Journalists (1998) Changing Definitions of News, published at http://www. journalism.org/lastudy3.htm

Galtung, Johan \& Ruge, Mari (1965): "The Structure of Foreign News: The Presentation of the Congo, Cuba and Cyprus Crises in Four Norwegian Newspapers", Journal of International Peace Research, vol. 1, pp. 64-91.

Harcup, Tony \& O'Neill, Deirdre (2001) "What is News? Galtung and Ruge revisited", Journalism Studies, vol. 2, no. 2, pp. 244-261

Grønnegaard, Michael \& Høivang, Kaj (2001) "Tv scorer millioner på presseomtale", Børsen, 16 May 2001.

Hesselager, Øjvind (2001) "Mediebryllup" and "Chefer siger nej”, Journalisten, no. 3. 
Hjarvard, Stig (1999) Tv-nyheder i konkurrence. Frederiksberg: Samfundslitteratur.

Jensen, Rolf (1999) The Dream Society. New York: McGraw-Hill.

Knudsen, Birgitte (2001) "Robinson Ekspeditionen sætter ny dagsorden i medierne”, eNews \& Views, ACNielsen AIM på URL: www.acnielsen.aim.dk
Langer, John ((1998) Tabloid Television. Popular Journalism and the "Other News", London: Routledge. Sparks, Colin (1998) "Introduction", The Public, vol. 5, no. 3.

Sparre, Kirsten \& Lars Kabel (2001) Den glade journalistik, Aarhus: Ajour. 